\title{
環状フローカプラの解析手法の開発
}

$\begin{array}{llllll}\text { 正 員 竹 } & \text { 中 } & \text { 清 } & \text { (電力中央研) } \\ \text { 正 員 根 本 孝 } \begin{array}{l}\text { (電力中央研) } \\ \text { 正 員 宅 間 }\end{array} \text { 董 } & \text { (電力中央研) }\end{array}$

\section{Development of Numerical Analysis for Annular Flow Coupler}

Kiyoshi Takenaka, Member, Koushichi Nemoto, Member, Tadasu Takuma, Member (Central Research Institute of Electric Power Industry)

A DC electromagnetic flow coupler is one of the candidate driving methods of liquid sodium coolant in liquid metal fast breeder reactors (LMFBR). The fundamental structure of a flow coupler consists of two flow channels connected electrically in series under a transverse magnetic field. When the conducting fluid in one of the channels is driven by an external means like a mechanical pump, this channel (generator channel) works under the magnetic field as a DC power supply. With the transverse magnetic field, the induced current provides a pumping force to the conducting fluid in the adjacent channel (pump channel), realizing a high efficiency DC electromagnetic pump. An annular electromagnetic flow coupler, in which a number of rectangular channels are arranged in an annular under a radial magnetic field, is considered to have the possibility of reducing the FBR size. This report gives a description of the analysis methods of flow couplers, and describes the calculated results on the flow and electrical characteristics of the experimental (prototype) annular flow coupler.

キーワード：電磁ポンプ，フローカプラ，ナビアストークス，有限要素法，高速增殖炉

\section{1.まえがき}

高速增殖炉 (FBR)の一次側ナトリウムの駆動方式 として，従来の機械式ポンプに替方るフローカプラが 注目されている(1)。これは導電性流体における電流と 磁界との相互作用で流体を駆動する電磁ポンプの一種 である。機械式ポンプなどで駆動された二次側ナトリ ウム(発電側)に一定磁界を加けて電流を発生させ，そ の電流を一次側ナトリウム(ポンプ側)に流して磁界と の作用で駆動する(図 1 )。

当所ては, 昭和 59 年度より方形断面のフローカフ ラ開発のためにメーカとの共同研究を開始し, 高温ナ トリウム中での原理実証試験, タンク形FBRに適用 した場合の概念設計を行うと共に, 数値計算手法の開 発を行ってきた。二次元有限要素法による電磁流体解 析プログラムと方形断面フローカプラの一部の解析結
果を既に報告している ${ }^{(2)}$ 。更に昭和 62 年度からは， 環状フローカプラ(後述図 9 ) 開発のためのメーカとの 共同研究を開始して高温ナトリウム中での原理実証試 験, 高効率化の検証から実証炉の小形スケールモデル (セクタモデル)の製作に進むと共に，数值計算による 解析手法の確立を目指した検討を進めている。その 間，環状フローカプラの側壁を絶縁することによっ て, 実験的に $50 \%$ を超える高効率を得られたことが 特筆される。

フローカプラの解析手法は基本的に次の 2 種類が ある。

（1）準一次元モデル(9) フローカプラを一次元 的な電流回路で構成してシミュレートするもので，側 壁の漏れ電流や端部効果などを考慮しており, 効率な ど全体的な特性を簡易に求めることができる。しか し，流速分布・電流分布を含めた詳細な解析や局所で 


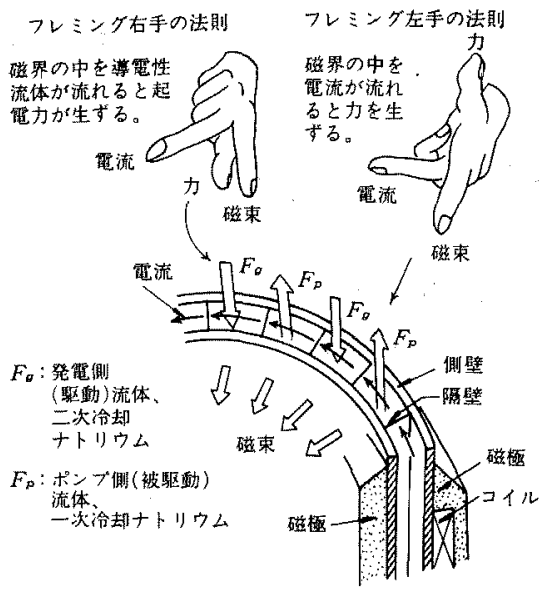

図 1 環状フローカプラ

Fig. 1. Annular flow coupler.

の特性を得ることはできず，また断面が方形でないと きなど理論条件からずれたときの誤差についても検詰 できない。

（2）有限要素法(2) 電磁界に関するマクスウェ ルの式と流体に関するナビアストークスの式を連立さ せて数值的に解く方法である。前述したように，方形 断面に扔ける二次元解析結果を既に報告している。

本報告は, 有限要素法による環状フローカプラ実験 機の特性解析結果, 特に流体の壁での速度条件を変え た検討結果を中心に，準一次元モデルの結果などをま とめたものについて述べる。

\section{2. 準一次元モテルによる解析}

準一次元モデルはもともとウェスティングハウス社 で開発されたものであり ${ }^{(3)}$ ，方形断面のフローカプラ が解析対象となっている。ところが, 環状フローカプ ラは，流路断面が扇状になっているだけではなく、フ ローカプラの磁束が減少する端部においても発電電流 をポンプ側に流し駆動力を発生している。このように 環状フローカプラは, 方形断面のフローカプラと比較 して, 幾つかの差異がある。そこで, 下記のように電 気特性・流体特性を考慮した。

（1）流体・壁などの導体を表現する電気的な等価 回路は，環状形状を考慮する。

（2）外部加ら印加する磁界は台形近似(直線近似) の分布とする。

（3）流体特性は, 璵状断面の曲率が小さいので Hunt らによる方形断面の特性式 (4) で近似する。

（4）磁束が減少する端部でも発電・ポンプの特性

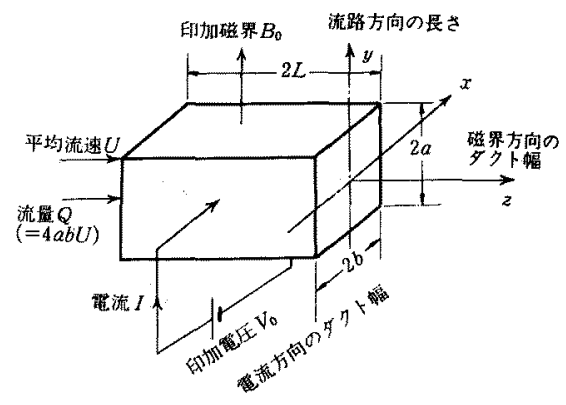

図 2 長方形断面の電磁流体

Fig. 2. Conducting fluid with rectangle sections.

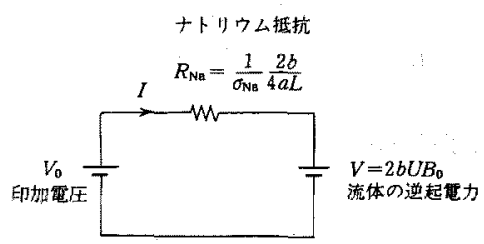

図 3 電磁流体の等価㷌路

Fig. 3. Equivalent circuit for a conducting fluid.

を考慮する。

（5）端部の磁束減少のための電位こう配で生じる 磁束一様部からの漏れ電流も一次近似で考慮する。

従って, 図1のような環状フローカプラにおいて, 電磁流体とダクトの電気的等価回路を作り，そのとき の圧力を求めることにより効率を計算する。

図 2 のよに長方形断面をもつ電磁流体が流速U で $Z$ 方向に流れている場合を考光る。そのときの電 流密度 $j$ は(1)式となる。

$$
j=\frac{I}{4 a L}=\sigma\left(E-U B_{0}\right)=\sigma\left(\frac{V_{0}}{2 b}-U B_{0}\right)
$$

ただし，2a：磁界方向のダクト幅， $2 b:$ 磁 界垂直方向のダクト幅, $2 L$ : 流路方向の電 極長さ, $B_{0}$ : 外部印加磁界の磁束密度, $\sigma$ : 流体の導電率, $V_{0}:$ 外部印加電圧, $E:$ 電界 強度, $I:$ 電流, $j:$ 電流密度, $U:$ 流体の平 均流速, $Q:$ 流体の流量 $(Q=4 a b U)$

電流 $I$ を求めると $(2)$ 式となる。

$$
I=\sigma \frac{4 a L}{2 b}\left(V_{0}-2 b U B_{0}\right)
$$

従って，等価回路は図 3 のようになる。

図1のようなステンレス隔壁で区切られた流路を電 磁流体としてナトリウムが流れる場合を考える。この 

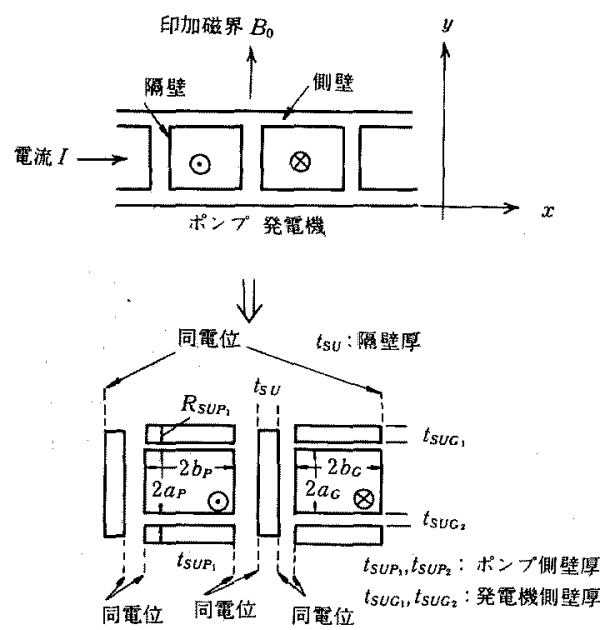

(a) 領域分割

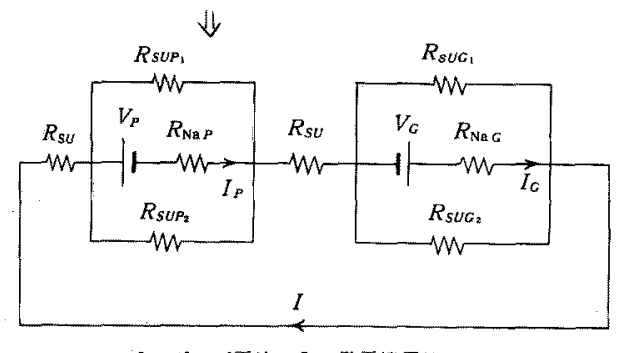

$I_{P}:$ ポンプ電流 $I_{C}:$ 笔電譏電流

$$
\begin{aligned}
& R_{\mathrm{NE} P}=\frac{2 b_{P}}{\sigma_{\mathrm{Na}}\left(2 a_{P} 2 L\right)} \quad R_{\mathrm{NBG}}=\frac{2 b_{G}}{\sigma_{\mathrm{Na}}\left(2 a_{G} 2 L\right)} \\
& R_{S U P_{1}}=\frac{2 b_{P}}{\sigma_{S U}\left(t_{S U P_{3}} 2 L\right)} \quad R_{S U G_{1}}=\frac{2 b_{C}}{\sigma_{S U}\left(t_{S U G_{1}} 2 L\right)} \\
& R_{S U P_{z}}=\frac{2 b_{P}}{\sigma_{S U}\left(t_{S U P_{z}} 2 L\right)} \quad R_{S U C_{2}}=\frac{2 b_{C}}{\sigma_{S U}\left(t_{S U G_{2}} 2 L\right)} \\
& R_{S U}=\frac{t_{S U}}{\sigma_{S U}\left(2 a^{2} L\right)} \\
& \text { の、ナトリウム導体の蒌電变 }
\end{aligned}
$$

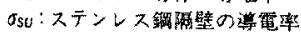

(b) 等䤄回路

図 4 フローカプラの領域分割と等価回路

Fig. 4. Equivalent circuit for a flow coupler.

ダクトを図 2 の電磁流体が $z$ 軸方向に交互に流れる 場合として環状フローカプラを扱う。 $y$ 方向の電位変 化がないものとすると図 4(a)の上うな領域に分割す ることができる。その等価回路は図 2 の等価回路と合 せて (b)図のようになる。

また，端部での磁束減少により生じた $z$ 方向の電 位傾斜て $z$ 方向に流れる電流は図 $5($ (a)のような電 流分布と考えられる。電流分布を(b)図の上うに仮定 すると片側ダクトのz方向に流出する全電流 $I_{E}$ は

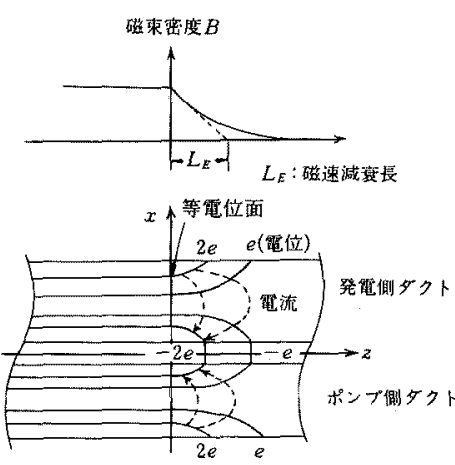

（a）端部での篋位・電流分布

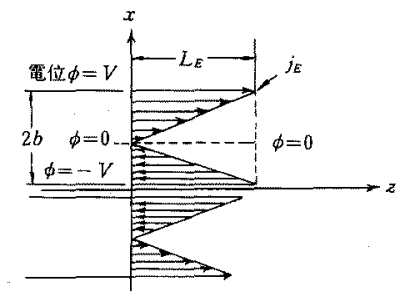

$j_{*}$ : 湖壁面での流体の霆流密度

$B=B_{0} \frac{L_{E}-z}{L_{E}}$ と近倒すると

$\phi \simeq V \frac{L_{E}-z}{L_{E}}$ となので

$j_{E}=-\sigma \frac{\partial \Phi}{\partial z}=\sigma \frac{V}{L_{E}}$

(b) 端部へ漏九る筆流の近似的分布

図 5 端部での磁束減少による電流

Fig. 5. Terminal effect by magnetic field.

$R_{S U P}=R_{S U P_{1}} / / R_{S U P_{2}} / / R_{E P_{1}} / / R_{E P_{2}} \quad R_{S U C}:$ 左试と同橉

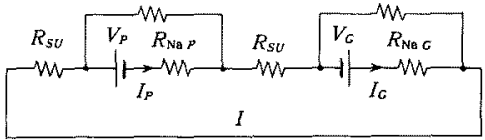

$R_{E P_{1}}=R_{E P_{2}}=\frac{L_{E}}{\sigma_{\mathrm{Na}} a_{P} b_{P}} \quad R_{E C_{4}}=R_{E C_{z}}=\frac{L_{E}}{\sigma_{\mathrm{Na}} a_{G} b_{C}}$

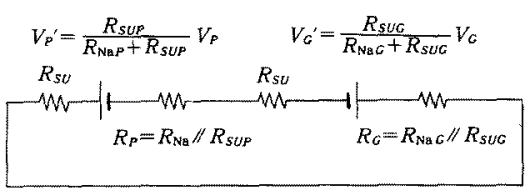

図 6 等価回路の簡単化

Fig. 6. Simplification of the equivalent circuit.

(3)式となる。

$$
I_{E}=\int_{-a}^{a} \int_{0}^{b} j_{E} \frac{x}{b} d x d y=a b j_{E}=\sigma \frac{a b}{L_{E}} V
$$


従って，その等価抵抗は(4)式となる。

$$
R_{E}=\frac{2 V}{I_{E}}=2 \frac{L_{E}}{\sigma a b}
$$

最終的な等価回路は図 6 のように簡単化できる。

従って，電流 $I$ は ( 5 )式となる。

$$
I=\left(V_{G}^{\prime}-V_{P}^{\prime}\right) /\left(R_{P}+R_{G}+2 R_{s U}\right)
$$

(各変数は図 4 , 図 6 参照)

またそれぞれの流体中を流れる電流 $I_{P} \cdot I_{C}$ は図 6 より

(6)式となる。

$$
\left.\begin{array}{l}
I_{P}=I-\left(V_{P}^{\prime}+I R_{P}\right) / R_{\mathrm{SUP}} \\
I_{G}=I+\left(V_{G}^{\prime}-I R_{G}\right) / R_{\mathrm{SUG}}
\end{array}\right\}
$$

ところが， $V_{G}, V_{P}$ は磁束密度 $B_{0}$ に比例するので, 電流・電圧はすべて $B_{0}$ に比例する。また電流 $I$ は $z$ 方向の流体長 $2 L に も$ 比例する。従って， $a, b$ など の大きさと流体・隔壁・側壁の導電率・粘性などの物 性值などが一定であれば比例定数を $i_{P}, i_{G}$ として $I_{P}$, Icは（7)式で表すことができる。

$$
\left.\begin{array}{l}
I_{P}=i_{P} B_{0} \times 2 L \\
I_{G}=i_{G} B_{0} \times 2 L
\end{array}\right\}
$$

この $i_{P}, i_{G}$ は $B_{0}=1,2 L=1$ のときの電流 $I_{P}, I_{C}$ か ら求められる。

次に図 2 の流体の $z$ 方向の圧力こう配を求める。 Hunt らによれば，(a)〜 (c) の仮定条件で圧力こう 配が与えられたときの流量 $Q$ は, 電磁流体のポンプ 側流速方向を正として，(8)式となる(4)。

(a) 二次流はなく，層流である。

（b）ダクト面積・磁界は $z$ 万向に変化しない。

(c) 導電率・電極は連続で流速方向に変化しない。

$$
\begin{aligned}
& Q=\left(\frac{B_{0} I}{4 a L}-\frac{\partial P}{\partial z}\right) \frac{4 a^{3} b}{\mu M} f(M, a, b) \\
& f=1-\frac{0.956 a}{b M^{1 / 2}}-\frac{1}{M}
\end{aligned}
$$

$P$ : 圧力, $\mu:$ 粘性係数, $M$ : ハルトマン数

$$
\left(M=a B_{0} \sqrt{\sigma / \mu}\right)
$$

圧力こう配を求めると $(9)$ 式となる。

$$
\begin{aligned}
\frac{\partial P}{\partial z} & =\frac{B_{0} I}{4 a L}-\frac{\mu M Q}{4 a^{3} b f} \\
& =\frac{B_{0} I}{4 a L}-\frac{\mu a B_{0} \sqrt{\sigma / \mu} 4 a b U}{4 a^{3} b f} \\
& =\left(\frac{I}{2 L}-\frac{2 \sqrt{\mu \sigma} U}{f}\right) \frac{B_{0}}{2 a} \cdots .
\end{aligned}
$$

$z$ 方向に流れる電流は図 $5($ a) で既に考慮されている ので, $z$ 方向に磁束が変化したときは微小長の範囲で は磁束が変化しないと考えることができる。従って， 全圧力差 $A P$ は $z$ 方向に圧力こう配を積分すれば
よい。

$$
\begin{aligned}
\Delta P & =\int \frac{d P}{d z} d z \\
& =\int\left(\frac{I(z)}{2 L}-\frac{2 \sqrt{\mu \sigma} U}{f}\right) \frac{B_{0}(z)}{2 a} d z
\end{aligned}
$$

(7)式より $I / 2 L=i B_{0}$ であるから(11)式となる。

$$
\Delta P=\int\left\{i B_{0}(z)-\frac{2 \sqrt{\mu \sigma} U}{f}\right\} \frac{B_{0}(z)}{2 a} d z
$$

磁束 $B_{0}$ が $z$ 方向に長さ $2 L$ の間変化しないときの全 圧力差は(12)式となる。

$$
\Delta P=\left(i B_{0}-\frac{2 \sqrt{\mu \sigma} U}{f}\right) \frac{2 L}{2 a} B_{0}
$$

磁束 $B_{0}$ が $z=0-L_{E}$ の間に $B_{0}(z)=B_{0} z / L_{E}$ と変化す るときの全圧力差は (13)式となる。

$$
\begin{aligned}
\Delta P & =\int_{0}^{L}\left(i B_{0} \frac{z}{L_{E}}-\frac{2 \sqrt{\mu \sigma} U}{f}\right) \frac{B_{0}}{2 a} \frac{z}{L_{E}} d z \\
& =\left(\frac{i}{3} B_{0}-\frac{\sqrt{\mu \sigma} U}{f}\right) \frac{L_{E}}{2 a} B_{0} \cdots \cdots \cdots \cdots(
\end{aligned}
$$

ただし，(12)式，(13)式の流速 $U$ はポンプ側流速を

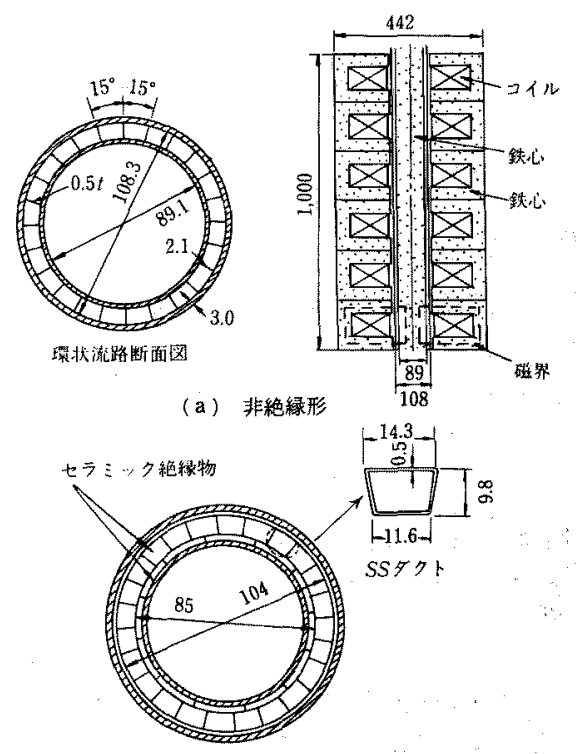

(b) 絶緑形

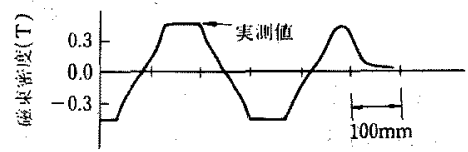

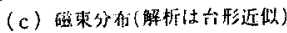

図 7 環状フローカプラ実験機

Fig. 7. Experimental flow coupler. 


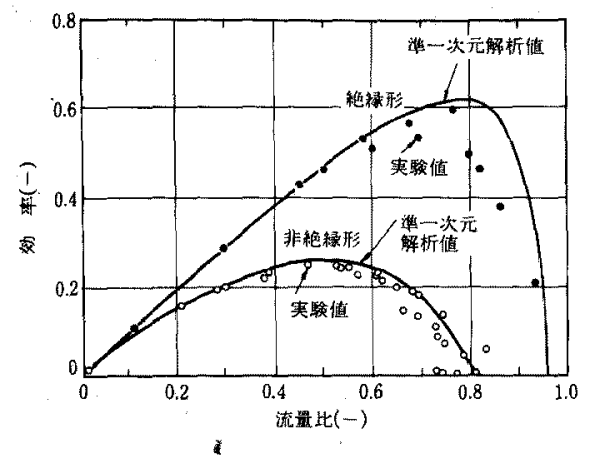

図 8 解析結果と実験結果の比較

Fig. 8. Comparison of analytic and experimental results.

正とした場合である。発電側の全圧力差を求める場合 は流速 $U$ に関する項の符号屿反転する。

そして, 効率 $\eta は(14)$ 式となる。

$$
\begin{aligned}
& \eta=\frac{Q_{P} \Delta P_{P}}{Q_{G} \Delta P_{G}} \\
& \Delta P_{P}= \int\left(i_{P} B_{0}(z)-\frac{2 \sqrt{\mu \sigma} U_{P}}{f}\right. \\
& \times \frac{B_{0}(z)}{2 a_{P}} d z \\
& \Delta P_{G}= \int\left(i_{G} B_{0}(z)+\frac{2 \sqrt{\mu \sigma} U_{G}}{f}\right. \\
& \times \frac{B_{0}(z)}{2 a_{G}} d z
\end{aligned}
$$

$Q_{P}$ : ポンプ側流量, $\Delta P_{P}:$ ポンプ側圧力差, $Q_{G}$ : 発電機側流量, $\Delta P_{G}:$ 発電側圧力差

高温ナトリウムを使用して, 発電側を外部ポンプで 駆動し，ポンブ側にバルブによる流路抵抗を加えた実 験(5)で使用した図 7 のようなフローカプラに，上記 までの計算を適用した。非絶縁形・絶縁形フローカプ ラは，同図に示すように，各ダクトの側壁としてステ ンレスを使用した構造と, セラミック絶縁体を使用し た構造である(5)。強度面や信頼性では非䋓緑形が優れ ているが，絶縁形では側壁での損失がなくなるので効 率向上が期待できる。両フローカプラに扔ける解析結 果と実験結果を比較したものを図 8 に示す。非絶縁 形・絶緑形七もに極めてよく合致して㕲り，この解析 手法が基本的に妥当であることを示している。

フローカプラのように，流路損失が数\%程度と小さ く，損失のほとんどがジュール損であり電位傾斜が一 様に近い場合，抵抗回路の表現が適切であれば理墖と 実験がよく合致する。

\section{3. 有限要素法による解析}

準一次元モデルでは，電流分布・速度分布は求めら れない。また，そもそもが大まかな近似であるため に，特にダクト楽面が長方形でない場合や，磁界が一 様でない場合にどの程度の詥差を生ずるのかかからな い。そのために, 有限要素法による解析が必要に なる。

本手法では，乱流ならびに誘導電流による磁界のひ ずみを無視し，現在のところ二次元場計算が可能とな つている。(15)式加ら（21）式の上うな方程式を解くの であるが，定常状態を対象としているので，以下のよ うに変換できる。

マクスウェルの方程式

$$
\begin{aligned}
& \nabla \cdot \vec{B}=0 \\
& \nabla \times \vec{H}=\vec{I} \\
& \text { ナビアストークスの式(非圧縮性) } \\
& \rho\left(\frac{\partial U}{\partial t}+\vec{U} \cdot \nabla \vec{U}\right)=\nabla \mu \nabla \vec{U}-\nabla P+\vec{I} \times \vec{B}
\end{aligned}
$$

オームの式

$$
\vec{I}=\sigma(\vec{E}+\vec{U} \times \vec{B})
$$

電流連続の式

$$
\nabla \cdot \vec{I}=0
$$

非圧縮性流体の連続の式

$$
\nabla \cdot \vec{U}=0
$$

$\sigma:$ 導電率, $\rho:$ 流体の密度, $\mu:$ : 流体の粘性

係数, $B$ : 磁束密度, $H$ : 磁界強度, $E$ : 電

界強度, $I:$ 電流密度, $U:$ 流体の流速,

$Q:$ 流体の流量, $P$ : 压力

定常状態を対象とすると $\nabla \times \vec{E}=0$ なので，電界 $\vec{E}$ はスカラポテンシャル(電位) $\emptyset$ 有する。従って,

(19)式と(20)式より

$$
\nabla^{2} \Phi=\nabla(\vec{U} \times \vec{B})
$$

となる。更に，(18)式の時間項を消去すると

$$
\rho \vec{U} \cdot \nabla \vec{U}=\nabla \mu \nabla \vec{U}-\nabla P+\vec{I} \times \vec{B}
$$

となる。(23)式の発散をとると

$$
\begin{aligned}
\nabla \cdot \nabla P= & -\nabla \cdot(\rho \vec{U} \cdot \nabla \vec{U})+\nabla \cdot(\nabla \mu \nabla \vec{U}) \\
& +\nabla \cdot(\vec{I} \times \vec{B}) \ldots \ldots \ldots \ldots \ldots \ldots \ldots \ldots \ldots \ldots
\end{aligned}
$$

となる。結局, 電位 $\emptyset$ は (22)式, 流速 $U$ は (23) 式, 圧力 $P$ は (24)式上り解く。そして, 有限要素として は, すべて四角形一次アイソパラメトリック要素を使 用している。なお，計算法の詳細は文献（2）の付録に 
記述している。

この手法図9に示すような，流路断面に $r, \theta$ 座 標, 流れ方向に $z$ をとる系に適用する。環状フロー カプラの構造は, $z=$ 一定の断面では二次元, また $r=$ 一定の断面では回転対称に近いが， $z$ 方向には磁 界が変化し， $\theta$ 方向には発電側ダクト $(G)$ とポンプ側 ダクト $(P)$ が連結されている。従って, 正確には三次

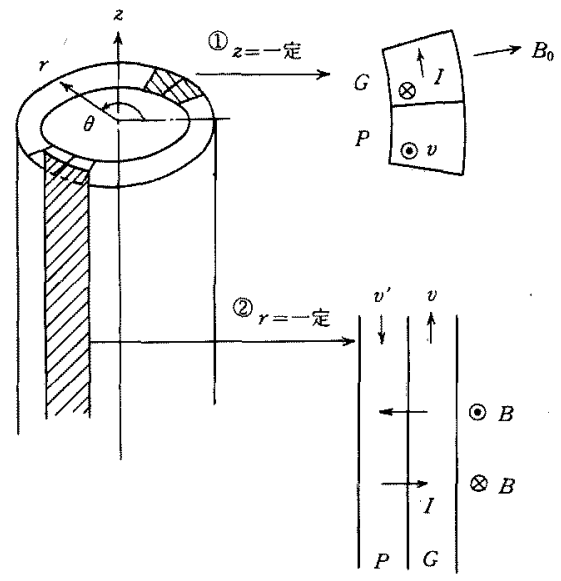

図 9 環状フローカプラの解析断面

Fig. 9. Cross sections for the analysis.
元構造として取扱わなければならず，二次元の計算結 果は近似結果である。たた，対称性や周期性から計算 領域を局限できる利点がある。図 9(1)2に計算した二 次元断面を示す。また，計算は図 7 のようなーロカ プラ実験機を対象として, 物性值も準一次元モテルと 同一のものを使用した。

$\langle 3 \cdot 1\rangle$ 流路断面 $(z=$ 一定)の結果 $z=-$ 定の 面では, 周期性から先に述へた構造の角度 30 度分の 1 ユニット(発電側招よびポンプ側がそれぞれ 1 ダク 卜分)を計算すればよい。非絶縁形フローカプラの計 算に用いたメッシュ分割は $14 \times 37$ で要素数 378 であ る。側壁および上下の隔壁は 2 層の要素で, 中間陻壁 は1層の要素で表現している。上下の隔壁の中間に 周期境界条件を圆き，流体条件は圧力こう配を一定 とした。図10に，一例として圧力こう配が発電側 $4.4 \mathrm{MPa} / \mathrm{m}$, ポンプ側 $1.5 \mathrm{MPa} / \mathrm{m}$ のとの $z$ 方向 の流速分布, 電位分布, 電流分布を示す（壁面ての速 度条件については次節で述べる。）。磁界は実駼条件 に相当する值として側壁外側で $0.48 \mathrm{~T}$ 一定とし，r に対する依存性 $(1 / r)$ を考慮している。

流速は発電側，ポンプ側ともそれそれのダクトの壁 付近に大さな速度こう配を有する分布で, 流速の最大 は発電側 $10.4 \mathrm{~m} / \mathrm{s}$, ポンプ 側 $5.5 \mathrm{~m} / \mathrm{s}$ (逆方向)であ.

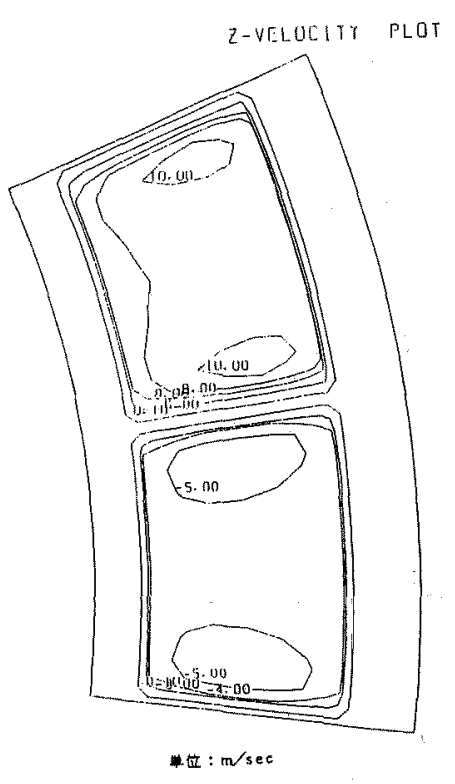

(a) 流速 $(z$ 方向) 分柿

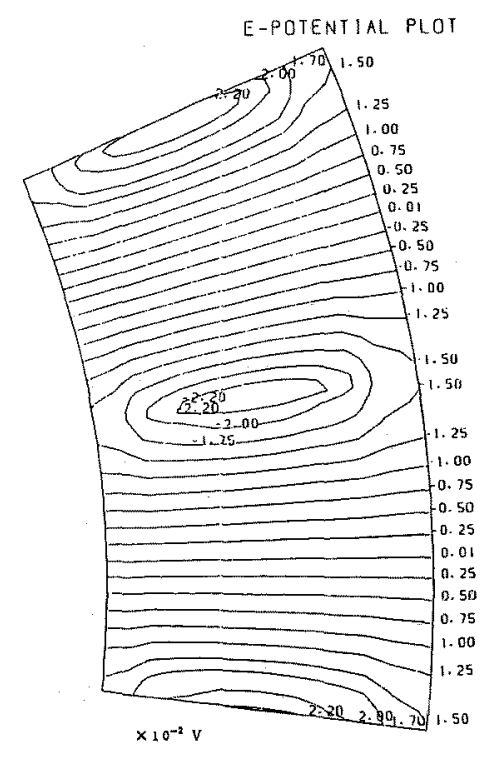

(b) 電位分布

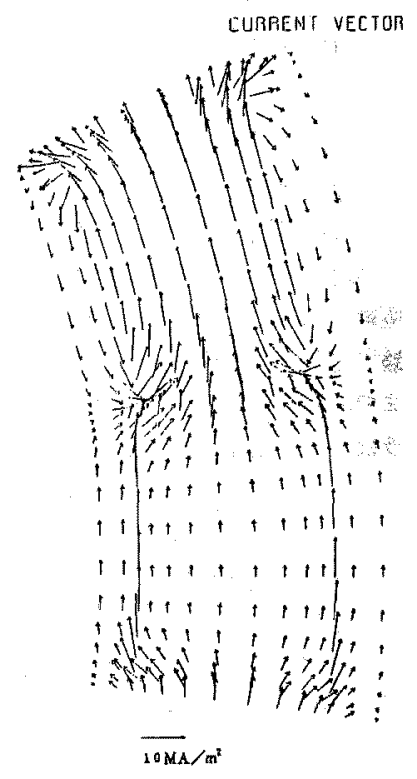

(c) 雪流密度分有

図 10 流路断面の特性(側壁非絶緑, 壁の速度条件 $A$ )

Fig. 10. Results on a vertical section to the liquid flow (conducting walls, boundary condition $A$ ). 


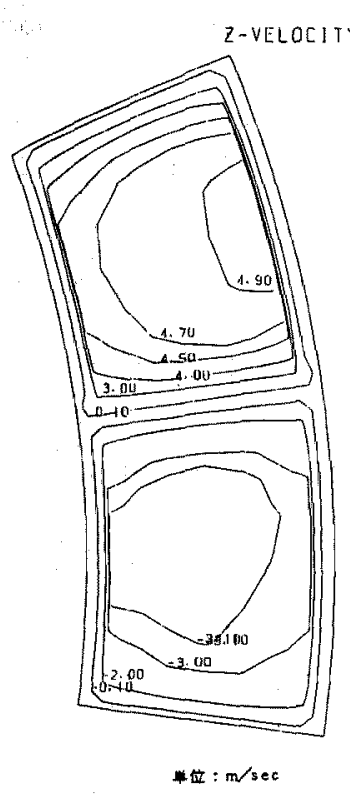

(a) 流速 ( 2 方向) 分布

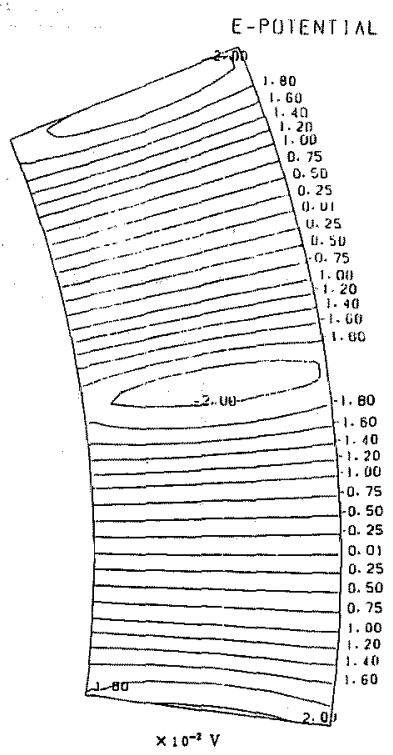

(b) 電位分布

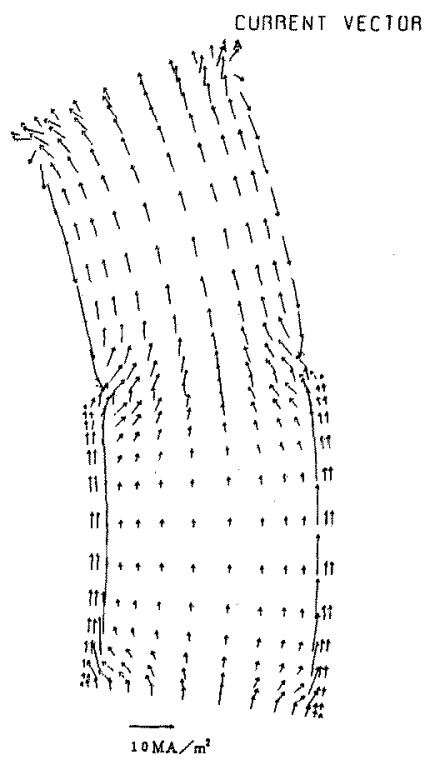

(c) 電流密度分布

図 11 流路断面の特性 (側壁絶縁，壁の速度条件 $A$ )

Fig. 11. Results on a vertical secton to the liquid flow (insulating walls, boundary condition $A$ ).

る。同(b)図からもわかるように，対称性から発電 側・ポンプ側の中央 $(\theta=$ 一定) に電位 $\Phi=0$ の条件が 成り立つので指定条件としている。電界 $\operatorname{grad} \emptyset$ ある はは電界電流 $\sigma \cdot \operatorname{grad} \Phi$ は図示していないが，それぞ れのダクト内でほぼ様で逆向き(発電側は図で下向 き，ポンプ側は上向きである。一方，全電流密度は $\sigma(-\operatorname{grad} \Phi+\vec{U} \times \vec{B})$ で, 第 2 項はどちらのダクトで も電界電流と逆向きであるから，結局同 $(c)$ 図のよう 電流密度分布となる。発電側の高い流速がダクト内 て電流(図で上向きを生ずるが，側壁内とダクトの側 壁付近では， $\vec{U} \times \vec{B}$ の電流が小さいため逆流になる。 ポンブ側では逆流は生じないが，流速の小さい側壁付 近では大きな電流になる。

図 11 k，絶緣形フローカプラの計算結果の各分布 を示す。図のようにポンプ側に流路分離用ダクト（厚 み $0.5 \mathrm{~mm}$ )があり, 側壁は 2 層の要素で計算してい る。計算条件は, 圧力こう配一定 (発電側 $4.4 \mathrm{MPa}$ / $\mathrm{m}$ ，ポンプ側 $1.8 \mathrm{MPa} / \mathrm{m}$ ), 磁界は $0.88 \mathrm{~T}$ 一定で 依存性を考慮している。非絶縁形と比べて， $z$ 方向の 流速分布は発電側では外側側壁の中央付近，ポンプ側 ては内側側壁の中央付近に最大値のある分布で, 最大 值は発電側 $3.2 \mathrm{~m} / \mathrm{s}$ ，ポンプ側 $1.1 \mathrm{~m} / \mathrm{s}$ でそれぞれか
なり小さくなっている。また，電流密度分布活，発電 側では逆流が側壁付近(のダクト内)だけになり，ポン プ側の側壁電流も側壁厚みが小さくなったため, 逆流 分は非絶緑形(図 10)上り著しく減少している。これ らの変化がそれぞれ効率向上をもたらすことが定性的 であるが予想できる。

\section{〈3.2〉 流れ方向の円周断面 $(\boldsymbol{r}=$ - 定)の結果}

図 9 の $r=$ 一定の断面として, ダクト中央部を二 次元配置で計算した。 $z$ 方向(流れ方向)には，6段の コイル(磁界のサイクルでは 3 サイクル)を含む約 $2 \mathrm{~m}$ をとり, $\theta$ 方向には各ダクト幅 15 度分のうちそ れぞれの中央部分に電位 0 の等電位線が生ずるとして 計算している。実際は $z$ 方向に長い形状なので，計 算結果では 2 方向は $1 / 10$ の寸法に縮小して示すこと とした。境界条件は実験值から発電側では $4.375 \mathrm{~m}$ $/ \mathrm{s}$ ，ポンプ側に $2.275 \mathrm{~m} / \mathrm{s}$ (逆方向)の一様流速ををれ ぞれダクト入ロに設定している。磁界は紙面に垂直 で，波高値 $0.48 \mathrm{~T}$ の正弦波である。

図 12 に, 非絶縁形フローカプラの場合の流速 $(z$ 方 向), 電位, 電流密度の計算結果を示す。すべて縋軸 を1/10に縮小した図面であるが，電流密度は矢印の 出発点の実際の (寸法比を変更しない)大きさ，方向を 


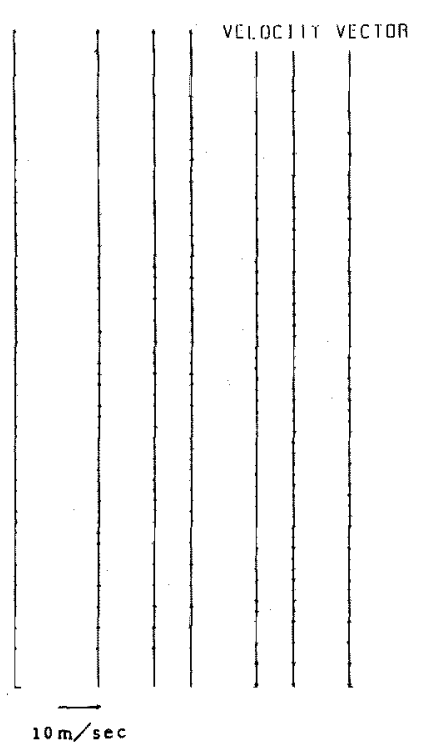

(a) 流速 ( 2 方向) 分布

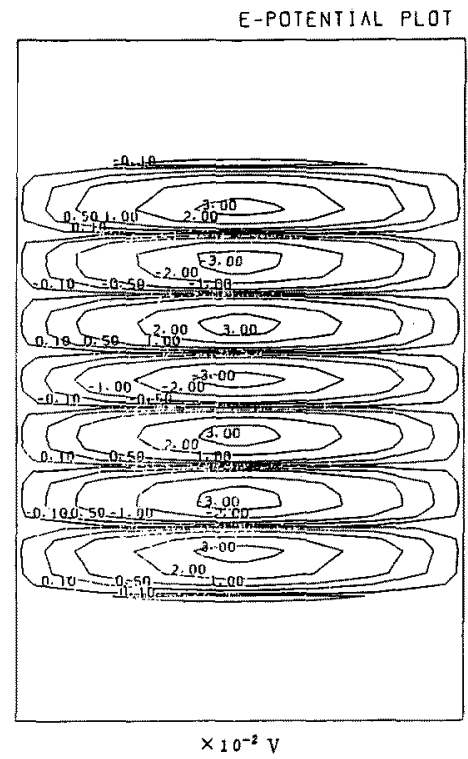

(b) 電位分布

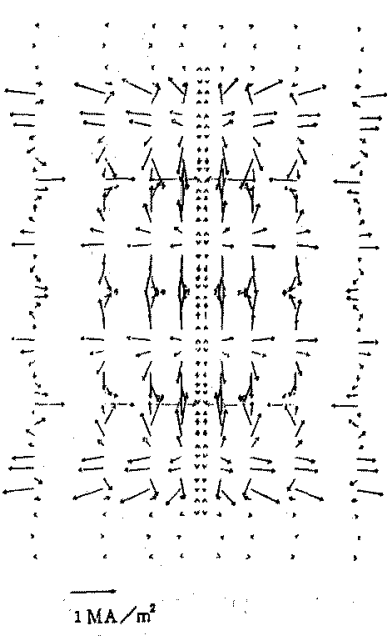

（c）電流密度行布

図 12 . 流れ方向の特性(側壁非絶縁, 壁の

速度条件 $A$ )

Fig. 12. Results on a vertical section to the magnetic flux (conducting walls, boundary condition $A$ ).

示している。電流の分布は駆動力となる紙面と水平な 左右への流れと共に，磁界 0 付近の上下への流れがあ り，ほぼ予想した分布になっている。また，磁界が 0 となる端部での電流は比較的小さい。

\section{4. 有限要素法による効率計算}

流体の壁面での速度は，粘性がわずかでもあれば理 論的には 0 である。ところが，電磁流体は磁界と垂直 な面ては，ごく薄い境界層(ハルトマン層)に大きな速 度こう配を生ずるが，フローカプラ実験機の場合に

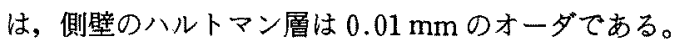
このような薄い層を有限要素法の分割で表現すること 㹥不可能で, むしろ速度 0 の条件をはずすほうが正し い特性に近いと考えることができる。一方，隔壁方向 には，ポアズイユ流(通常の粘性流)の特性になるが， ナトリウムの粘性が小さい(髇やすい)。そこで，有 限要掌法によるフローカプラの解析において，その側 壁・隔壁での速度境界条件の妥当性を検討するため, 下記のような 3 種類の速度条件を設定した。

$A$, 粘性流：壁面(隔壁，側壁)で速度 0

$B$, 片滑り：隔壁では速度 0, 側壁では滑りが ある。

C，両滑り：隔壁，側壁とも滑りがある。
この3 条件に抢ける流路断面を有限要素法で解析 した。

壁面の速度条件 $B$ (片滑り)の場合の結果では, 速 度分布注速度条件 $A$ (粘性流) と比較して大きな速度 こう配は隔壁付近だけとなっている。電位分布・電流 密度分布の変化は速度分布ほど大きくないが, 図 13 と図 10 の比較からわかるように, 粘性流でないため 発電側での側壁付近(ダクト内)での電流の逆流㧍よび ポンプ側での大きな電流がなくなっている。また，速 度条件 $C$ (両滑り)の場合の結果ては，隔壁付近での 大きな速度こう配もなくなり，一様流に近くなってい る。電位分布・電流密度分布の変化は壁の速度条件 $B$ とほとんど変わらない。

更に,これらの壁の速度条件の妥当性を定量的に椧 討するため，二次元の流路断面に扔けるフローカプラ の効率を求めた。効率は，各条件における解析結果の 速度分布を断面全体て積分して流量を求め，以下の式 から計算される。

効率 $\eta=\left(Q_{P} \Delta P_{P}\right) /\left(Q_{G} \Delta P_{G}\right)$

ここで， $Q_{P}:$ ポンプ側流量(ポンプ側ダクト

の流体速度の断面積分)， $Q_{G}$ : 発電側流量

(発電側ダクトの流体速度の断面積分), $\Delta P_{P}:$ ポンプ側ダクト圧力こう配, $\Delta P_{G}$ : 発 


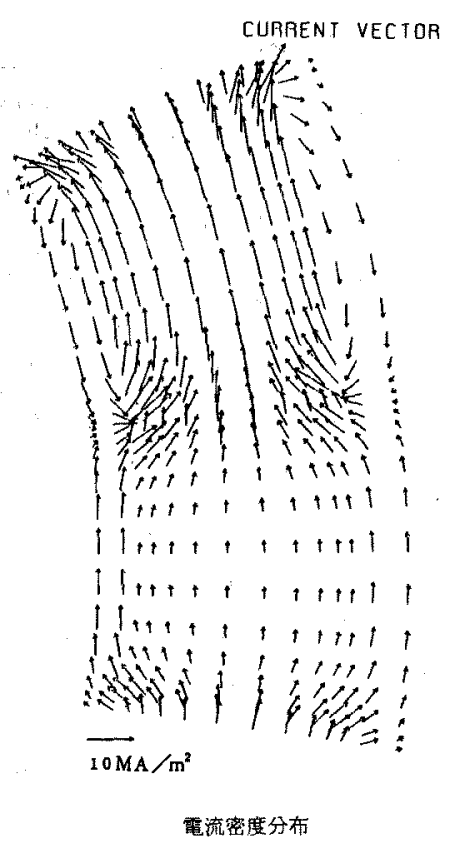

図 13 流路断面の特性(側壁非絶緑，速度 条件 B)

Fig. 13. Results on boundary condition $B$.

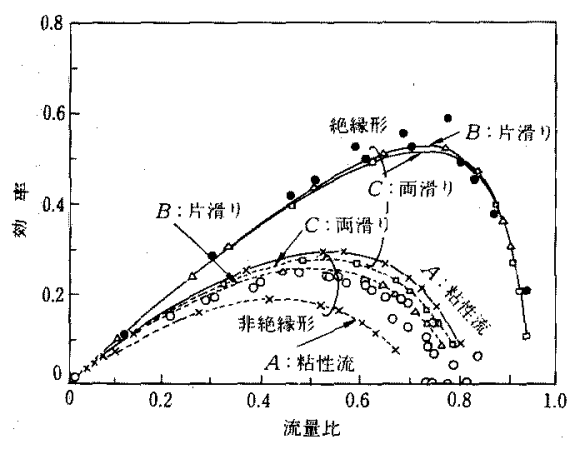

図 14 有限要素法の解析結果と実験結果 の比較

Fig. 14. Comparison of analytic results by FEM and experimental results.

電側ダクト圧力こう配

この式は(14)式と同一であるが，各変数の求め方が異 なる。ボンプ側ダクトと発電側ダクトの圧力こう配の 比をパラメータとして変化し，流量比を基準としてま とめた結果を図 14 亿示す。压力こう配比が一定であ れば，珐力こう配の大きさそのものによる影響ははと んどなかったので圧力こう配比をパラメータとした。

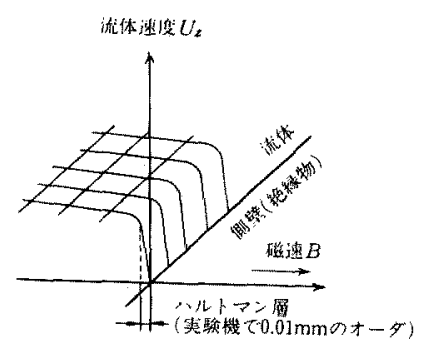

（a）流体速度分有

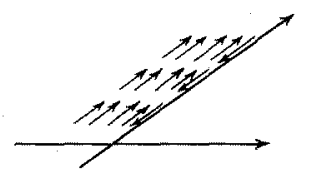

(b) 電流密度分布

図 15 ハルトマン層の速度分布および 電流分布

Fig. 15. Flow velocity and current density in Hartmann layer.

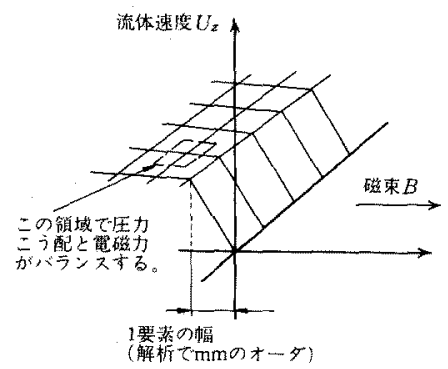

(a) 流体速度分布

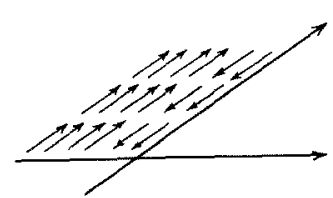

(b) 電流密度分布

図 16 有限要素法による速度分布扝よび 電流分布

Fig. 16. Flow velocity and current density by FEM.

この結果から明らかなように，速度条件 $A$ では計 算結果が実験結果を大きく下回った。また，速度条件 $B ， C$ では実験結果とほとんど同じ結果であるが，非 絶縁形については, 速度条件 $B($ 片滑り)の合致度が 良くなった。つまり，速度条件 $A$ を用いた計算では 実現象を正確に評価しておららず，数值計算上では速度 
条件 $B \cdot C$ のほうがより実現象に近いことを示して いる。

磁束が通過する(磁界と垂直な)側壁にできる速度分 布が急峻となるハルトマン層の速度分布を図 15(a) に示す。壁面の速度条件 $A$ は，このハルトマン層を 図16(a)のように分割要素一つで近似している。と ころが, 図7のような実験機のハルトマン層は $0.01 \mathrm{~mm}$ のオーダであり，ハルトマン層を過大に評 価する結果となっている。つまり，図 16(a)のよう に外部から与えられる圧力こう配と $\vec{U} \times \vec{B}$ にって 生じる電磁力のバランスを有限要素の格子点でとり, 側壁の速度 0 の条件の間を直線近似(一次近似)するた めに図 $15(\mathrm{~b})$ と図 $16(\mathrm{~b})$ のように電流分布に大きな 差を生じるのである。従って, その要素一つ(ハルト マン層を含む境界領域)を通過する電流がオーダ的に 大きくなり，損失が増大して効率の低下を生じると考 えられる。

従って, ハルトマン層が分割要素より極端に小さく なる流体要素では, 特別にハルトマン層を近似する手 法を開発するか，側壁の速度条件として流体に滑りが ある速度境界条件の採用がより正確であることが明ら かとなった。

\section{5. まと め}

フローカプラポンプの解析手法として開発した準一 次元モデルおよび有限要素法による解析手法について 述べた。実験結果との対比からそれらの有効性が確認 された。また, 有限要素法においては, ハルトマン層 が分割要素より極端に小さくなる壁近傍では，流体に 滑りがある速度境界条件がより正確であることが明ら かとなった。

最後に本論文を作成するにあたり，有意義な御討論 をいただきました当所電力システム部長 坪井昭氏， 同部系統計画研究室長 長尾待士氏に深く感謝致しま す。また, 有限要素法解析においてプログラム開発お よび特性解析に御協力いただきました三菱総研安田 英典氏および電力計算センタ 鈴木重隆氏に深く感謝 すると共に，計算結果に関して御討論いただきました 東大工学部原子力工学科宮健三教授, 高木敏行助教 授，当所原子力総合推進室 FBR グループ湊章男氏， 狛江研究所 FBR 部革新炉研究室 三宮豊氏，送配電部 放電研究室 吉田智朗氏に感謝致します。

(平成元年 11 月 28 日受付)

\section{文献}

（1）電力中央研究所：〔環状フローカプラーポンプ型モジュール 炉」，第 5 回エネルギー未来技術フォーラム技術パンフレッ 卜 (昭 61)

（2）根本·宅間：「フローカプラーポンプの解析」, 電力中央研究 所研究報告, No. T 87092 (昭 62)

(3) W. F. Hughes \& I. R. McNab: "Liquid Metal Flows and Magnetohydrodynamics", Progress in Astronautics and Aeronativs, 84, 287(1983)

(4) J. C. R. Hunt \& K. Stewartson: "Magnetohydrodynamic flow in rectangular ducts", J. Fluid Mech., 23, 563(1965)

(5) T. Ikeda, S. Hattori et al.: "Sodium Tests of Head Flow Characteristics for a Prototype Annular Electromagnetic Flow Coupler", LIMET ' 88

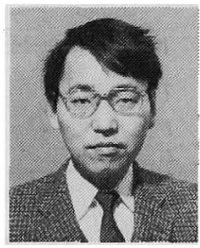

竹 中 清（正員）

昭和 28 年 5 月 31 日生。 53 年 3 月大阪大学工学研究科電気工学専攻 修士課程修了。同年 4 月 (財)電力中 央研究所入所。フローカプラポン プ, 直流送電, 電圧安定性, 分散電源の解析・シミュ レーションなどの研究に従事。58 年電気学会論文賞 受章。

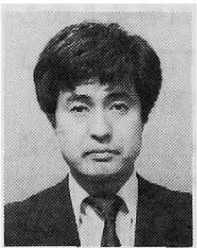

根 本 孝 七（正員）

昭和 34 年 7 月 16 日生。 59 年 3 月東京大学大学院修士課程修了。同 年 4 月 (財)電力中央研究所入所, 現 在に至る。電磁フローカプラポンプ の解析およびレーザー装置の開発に従事。

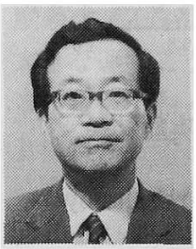

宅間董（正員）

昭和 13 年 9 月 30 日生。 41 年 3 月東京大学大学院博士課程修了。 41 年 4 月同大学電気工学科講師。工学 博士。 42 年 4 月 (財) 電力中央研究 所入所。放電, 絶縁, 電界計算, 電気環境, エネルギ 一問題に関する研究に従事。 46 年および平成元年電 気学会論文賞, 50 年イギリス電気学会 Maxwell 賞, 56 年電気学会著作賞受賞。平成元年電気学会編集理 事。同年 4 月九州大学総合理工学研究科客員教授。 